\title{
EKONOMI BIRU: SOLUSI PEMBANGUNAN DAERAH BERCIRI KEPULAUAN STUDI KASUS KABUPATEN KEPULAUAN ANAMBAS
}

\section{THE BLUE ECONOMY: AN ISLANDS REGIONAL DEVELOPMENT SOLUTION THE CASE STUDY ON ANAMBAS ISLANDS REGENCY}

\author{
Herie Saksono \\ Pusat Penelitian dan Pengembangan Pemerintahan Umum dan Kependudukan \\ Badan Penelitian dan Pengembangan (BPP)- Kementerian Dalam Negeri \\ Jl. Kramat Raya No. 132 - Senen, Jakarta \\ Nomor Telp./Faks: +62 21314 0454; e-mail:herie.saksono@yahoo.com \\ Dikirim: 27Februari2013, Diterima Setelah Perbaikan: 17Maret 2013
}

\begin{abstract}
Abstraksi
Studi ini bertujuan untuk lebih memahami eksistensi ekonomi biru sebagai solusi pembangunan daerah berciri kepulauan.Kondisi geografis dan fenomena alam di wilayah kepulauan mengakibatkan pembangunan di wilayah tersebut seringkali terkendala. Ekonomi biru merupakan aktivitas perekonomian yang mengandalkan pengelolaan sumberdaya lokal oleh masyarakat setempat (inklusif) yang menuntut kreativitas, inovasi, efisiensi, dan efektivitas, tanpa menyisakan limbah. Pendekatan pengembangan yang digunakan adalahkualitatif dengan metode analisis deskriptif. Locus studi di Kabupaten Kepulauan Anambas. Hasil analisis membuktikan bahwa pembangunan daerah berbasis ekonomi biruyang diintegrasikan dengan program/kegiatan pembangunan darat menjadi sinergi baru yang mampu memberi nilai tambah ekonomi, berdaya saing, dan bermanfaat untuk percepatan pembangunan daerah kepulauan. Dalam operasionalisasinya, direkomendasikan kepadaPemerintah maupunpemerintahan daerah agar memiliki komitmen dan keberpihakan dalam penataan regulasi/kebijakan termasuk alokasi anggarannyademi kemajuan sosial dan kesejahteraan masyarakat kepulauan.
\end{abstract}

Kata kunci: ekonomi biru, pembangunan daerah, dan kepulauan.

\begin{abstract}
This study aims to make a better understanding about blue economic existence as a solution for regional development of island characteristic. The islands geographical condition and natural phenomena has hinder the islands development. Blue Economy is an economic activities relies on local resources managed by local inhabitants, which demands creativity, innovation, efficiency, and effectivenesswithout leaving any waste. This study use qualitative development approach with descriptive analysis method. The analysis results proved that blue economic-base regional development which integrated with land development program/action, become a new synergies able to add economic value, competitiveness, and useful to accelerate regional development of island characteristic. In its implementation, it's highly recommended that Central and Local Government must have commitment, and support on regulation/policy structuring including budget allocation, for social well-being and the welfare of the islands population.
\end{abstract}

Keywords: blue economy, regional development and islands

\section{PENDAHULUAN}

Sebagai negara kepulauan, Indonesia terdiri dari wilayah daratan dan lautan. Jumlah pulau di Indonesia, baik yang besar maupun yang kecil, mencapai 17.508 pulau. Argumentasi inilah yang mendasari penyebutan Indonesia sebagai “Archipelagic State".Berdasarkan hasil Konvensi Hukum Laut Internasional atau "United Nation Convention on the Law of the Sea" (UNCLOS) pada tanggal 10 Desember 1982 di Montego Bay, Jamaica,luas wilayah laut Indonesia mencapai $3.257 .357 \mathrm{~km}^{2}$, dengan batas wilayah laut/teritorial dari garis dasar kontinen sejauh 12 mil diukur dari garis dasar, sedangkan luas daratannya mencapai
1.919.443 $\mathrm{km}^{2}$. Secara menyeluruh, luas wilayah lautan dan daratan mencapai 5.176 .800 $\mathrm{km}^{2}$ (http://id.shvoong.com/social-sciences/sociology /2257902-luas-wilayah-indonesia/ Diunduh: 11 Oktober 2012).

Mengacu pada luasan wilayah darat dan laut, diperlukan strategi yang baik dalam pembangunan dan pengelolaan sumber-sumber daya yang dimilikinya, sehingga peningkatan kesejahteraan masyarakat sebagai tujuan berdirinya negara dapat terwujud sesegera mungkin dan merubah kualitas hidup masyarakatnya. Negara menjadi lebih sejahtera ketika para pengelolanya mampu menumbuhkan inovasi, memanfaatkan kearifan lokal 
yang ada di sekitarnya dan didukung sepenuhnya oleh partisipasi masyarakatnya.

Arcipelagic State merupakan karakteristik negara nusantara yang memiliki banyak pulau. Potensi dari berbagai pulau tersebut dapat dimanfaatkan sebagai sumber-sumber inspirasi, kreasi, dan inovasi yang memberikan nilai tambah ekonomi bagi pemerintah maupun masyarakatnya di pusat sampai ke seluruh pelosok negeri.

Persoalan kemudian timbul, ketika terjadi ketidakmampuan dan kesenjangan kualitas dalam proses mengidentifikasi, merencanakan, mengelola, mengawasi, mengoptimalkan, dan menjaga keberlanjutan potensi daerah kepulauan tersebut. Menurut Kepala Pusat Analisis Kerjasama Internasional dan Antar Lembaga pada Sekretariat Jenderal Kementerian Kelautan dan Perikanan (KKP) Anang Noegroho, dinyatakan bahwa rata-rata selama satu dekade terakhir, negara mengalami kerugian sebesar Rp 30 triliun pertahun sebagai akibat dari pencurian oleh negara asing. Jika, harga satu kilogram ikan adalah dua dolar (US \$ 2), maka hal ini berarti jumlah ikan yang dicuri mencapai 166 ton pertahun. (http://www.kkp.go.id/index.php/arsip/

Tabel 1. Komposisi Kabupaten/Kota Berkarakter Kepulauan dan/atau Memiliki Wilayah Pesisir/Laut Menurut Provinsi Tahun 2012

\begin{tabular}{|c|c|c|c|c|c|c|c|c|c|c|}
\hline \multirow[b]{2}{*}{ No. } & \multirow[b]{2}{*}{ Provinsi } & \multicolumn{4}{|c|}{$\begin{array}{l}\text { Daerah Memiliki Laut/ } \\
\text { Berkarakter Kepulauan }\end{array}$} & \multicolumn{4}{|c|}{$\begin{array}{l}\text { Daerah Tanpa Laut } \\
\text { (Landlock Region) }\end{array}$} & \multirow{2}{*}{$\begin{array}{c}\Sigma \\
\text { Total } \\
\Sigma^{1}+\Sigma^{2} \\
\text { (Kab. } \\
\& \\
\text { Kota) }\end{array}$} \\
\hline & & $\begin{array}{c}\Sigma \\
\text { Kab. } \\
(1)\end{array}$ & $\begin{array}{c}\Sigma \\
\text { Kota } \\
(2)\end{array}$ & $\begin{array}{c}\Sigma^{1} \\
(1+2)\end{array}$ & $\begin{array}{c}\% \\
\text { Thd } \\
\Sigma \\
\text { Total }\end{array}$ & $\begin{array}{c}\Sigma \\
\text { Kab. } \\
(3)\end{array}$ & $\begin{array}{c}\Sigma \\
\text { Kota } \\
(4)\end{array}$ & $\begin{array}{c}\Sigma^{2} \\
(3+4)\end{array}$ & $\begin{array}{c}\% \\
\text { Thd } \\
\Sigma \text { Total }\end{array}$ & \\
\hline 1. & Aceh & 14 & 4 & 18 & 78,26 & 4 & 1 & 5 & 21,74 & 23 \\
\hline 2. & Sumatera Utara & 13 & 3 & 16 & 48,48 & 12 & 5 & 17 & 51,52 & 33 \\
\hline 3. & Sumatera Barat & 5 & 2 & 7 & 36,84 & 7 & 5 & 12 & 63,16 & 19 \\
\hline 4. & Riau & 6 & 1 & 7 & 58,33 & 4 & 1 & 5 & 41,67 & 12 \\
\hline 5. & Kepulauan Riau & 5 & 2 & 7 & 100,00 & 0 & 0 & 0 & 0,00 & 7 \\
\hline 6. & Jambi & 2 & 0 & 2 & 18,18 & 7 & 2 & 9 & 81,82 & 11 \\
\hline 7. & Sumatera Selatan & 3 & 0 & 3 & 20,00 & 8 & 4 & 12 & 80,00 & 15 \\
\hline 8. & Kep. Bangka Belitung & 6 & 1 & 7 & 100,00 & 0 & 0 & 0 & 0,00 & 7 \\
\hline 9. & Bengkulu & 6 & 1 & 7 & 70,00 & 3 & 0 & 3 & 30,00 & 10 \\
\hline \multirow[t]{2}{*}{10.} & Lampung & 6 & 1 & 7 & 50,00 & 6 & 1 & 7 & 50,00 & 14 \\
\hline & SUMATERA & 66 & 15 & 81 & 53,64 & 51 & 19 & 70 & 46,36 & 151 \\
\hline 11. & DKI Jakarta & 1 & 1 & 2 & 33,33 & 0 & 4 & 4 & 66,67 & 6 \\
\hline 12. & Jawa Barat & 10 & 1 & 11 & 42,31 & 7 & 8 & 15 & 57,69 & 26 \\
\hline 13. & Banten & 4 & 2 & 6 & 75,00 & 0 & 2 & 2 & 25,00 & 8 \\
\hline 14. & Jawa Tengah & 14 & 3 & 17 & 48,57 & 15 & 3 & 18 & 51,43 & 35 \\
\hline 15. & DI Yogyakarta & 3 & 0 & 3 & 60,00 & 1 & 1 & 2 & 40,00 & 5 \\
\hline \multirow[t]{2}{*}{16.} & Jawa Timur & 19 & 3 & 22 & 57,89 & 10 & 6 & 16 & 42,11 & 38 \\
\hline & JAWA & 51 & 10 & 61 & 51,69 & 33 & 24 & 57 & 48,31 & 118 \\
\hline 17. & Bali & 7 & 1 & 8 & 88,89 & 1 & 0 & 1 & 11,11 & 9 \\
\hline 18. & Nusa Tenggara Barat & 8 & 2 & 10 & 100,00 & 0 & 0 & 0 & 0,00 & 10 \\
\hline \multirow[t]{2}{*}{19.} & Nusa Tenggara Timur & 20 & 1 & 21 & 100,00 & 0 & 0 & 0 & 0,00 & 21 \\
\hline & $\begin{array}{l}\text { BALI - NUSA } \\
\text { TENGGARA }\end{array}$ & 35 & 4 & 39 & 97,50 & 1 & 0 & 1 & 2,50 & 40 \\
\hline 20. & Kalimantan Barat & 6 & 1 & 7 & 50,00 & 6 & 1 & 7 & 50,00 & 14 \\
\hline 21. & Kalimantan Tengah & 7 & 0 & 7 & 50,00 & 6 & 1 & 7 & 50,00 & 14 \\
\hline 22. & Kalimantan Selatan & 5 & 0 & 5 & 38,46 & 6 & 2 & 8 & 61,54 & 13 \\
\hline \multirow[t]{2}{*}{23.} & Kalimantan Timur & 8 & 3 & 11 & 78,57 & 2 & 1 & 3 & 21,43 & 14 \\
\hline & KALIMANTAN & 26 & 4 & 30 & 54,55 & 20 & 5 & 25 & 45,45 & 55 \\
\hline 24. & Sulawesi Utara & 11 & 2 & 13 & 86,67 & 0 & 2 & 2 & 13,33 & 15 \\
\hline 25. & Gorontalo & 5 & 1 & 6 & 100,00 & 0 & 0 & 0 & 0,00 & 6 \\
\hline 26. & Sulawesi Tengah & 9 & 1 & 10 & 90,91 & 1 & 0 & 1 & 9,09 & 11 \\
\hline 27. & Sulawesi Selatan & 15 & 3 & 18 & 75,00 & 6 & 0 & 6 & 25,00 & 24 \\
\hline 28. & Sulawesi Barat & 4 & 0 & 4 & 80,00 & 1 & 0 & 1 & 20,00 & 5 \\
\hline \multirow[t]{2}{*}{29.} & Sulawesi Tenggara & 10 & 2 & 12 & 100,00 & 0 & 0 & 0 & 0,00 & 12 \\
\hline & SULAWESI & 54 & 9 & 63 & 86,30 & 8 & 2 & 10 & 13,70 & 73 \\
\hline 30. & Maluku & 9 & 2 & 11 & 100,00 & 0 & 0 & 0 & 0,00 & 11 \\
\hline \multirow[t]{2}{*}{31.} & Maluku Utara & 7 & 2 & 9 & 100,00 & 0 & 0 & 0 & 0,00 & 9 \\
\hline & MALUKU & 16 & 4 & 20 & 100,00 & 0 & 0 & 0 & 0,00 & 20 \\
\hline 32. & Papua & 12 & 1 & 13 & 44,83 & 16 & 0 & 16 & 55,17 & 29 \\
\hline \multirow[t]{3}{*}{33.} & Papua Barat & 9 & 1 & 10 & 90,91 & 1 & 0 & 1 & 9,09 & 11 \\
\hline & PAPUA & 21 & 2 & 23 & 57,50 & 17 & 0 & 17 & 42,50 & 40 \\
\hline & INDONESIA & 269 & 48 & 317 & 63,78 & 130 & 50 & 180 & 36,22 & 497 \\
\hline
\end{tabular}

Sumber: Berbagai Sumber. Data Diolah. 2012. 
Tabel 2.

Luas Wilayah, Jumlah Kabupaten/Kota yang Memiliki Laut/Berkarakter Kepulauan, dan Jumlah Pulau Menurut Provinsi - Tahun 2011

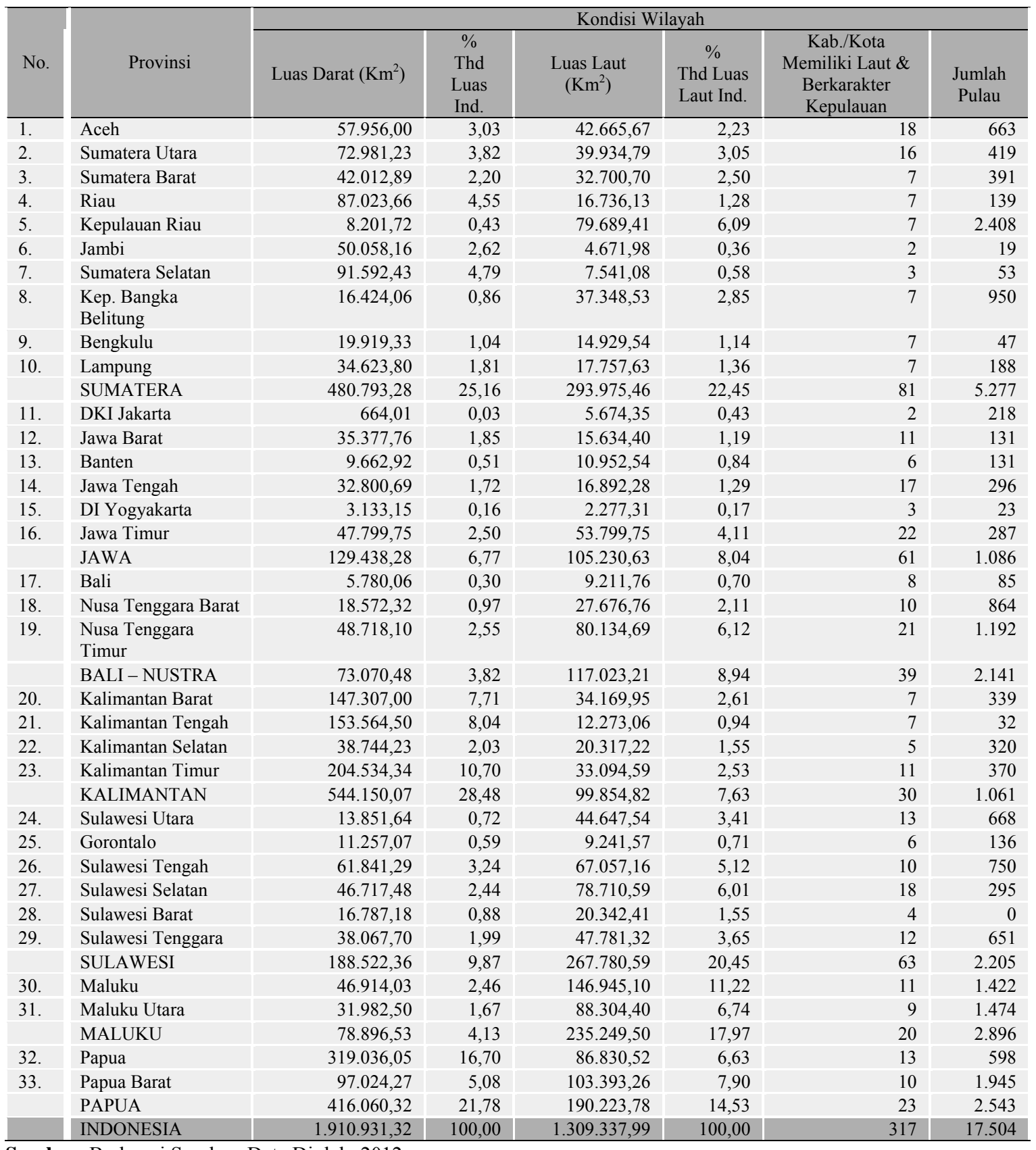

Sumber: Berbagai Sumber. Data Diolah. 2012.

c/7922/Ekonomi-Biru-Menjadi-Kunci-Pembangunan -KP-Kedepan/? category id=34, Diunduh: 10 Oktober 2012).

Luasnya wilayah laut yang dimiliki membutuhkan manajemen pengelolaan yang tepat dan baik. Pengelolaan tersebut dibutuhkan agar potensi dan pemanfaatannya dapat bermakna, memberikan keuntungan, dan bahkan nilai tambah bagi kehidupan masyarakat. Sampai saat ini, potensi kelautan yang besar di Indonesia belum dapat dimanfaatkan dengan baik. Mencermati besarnya nilai kerugian yang ditimbulkan dari pencurian potensi kelautan tesebut, semakin nampak lebarnya kesenjangan manakala hasil potensi daerah kepulauan tersebut dapat dimanfaatkan oleh para nelayan dan masyarakat.Di sisi lain, pada tahun 2011,tercatat bahwa ekspor perikanan Indonesia hanya mencapai US\$ 3,34 Milyar.Hal ini membuktikan semakin tertinggal Indonesia jika dibandingkan dengan Vietnam yang berhasil mencapai US\$ 25 Milyar. (http://ekonomi.kompasiana.com/bisnis/2012/09/07/ potensi-ekonomi-di-laut-dan-wilayah-pesisir- 
indonesia-mencapai-us12-trilyun/, Diunduh: Oktober 2012).

Sangat disayangkan pengelolaan potensi kelautan di daerah-daerah kepulauan nampaknya belum didukung inovasi yang dipadupadankan dengan kearifan lokal yang didorong oleh partisipasi masyarakat. Ketiga hal tersebut menjadi instrumen transformasi yang komprehensif, ketikapara pemangku kepentingan berupaya melakukan perbaikan terhadap sistem regulasi/kebijakan, pengembangan kapasitas kelembagaan, pembenahan tata kelola, dan peningkatan kualitas sumber daya manusia (SDM)yang mampu menjamin kelestarian lingkungan dan keberlanjutan pembangunan. Maknanya, setiapinovasi yang ditumbuhkan harus mengadopsi nilai-nilai budaya lokal sebagai suatu kearifan bersama setempat yang dimiliki dan diwarisi secara turun-temurun.

Potensi kelautan yang begitu besar memerlukan perencanaan yang matang oleh daerah yang memiliki wilayah laut. Secara teknis, terutama pada pembangunan laut dan pesisir, diharapkan dapat berpatokan pada strategi pembangunan yang berbasiskan Blue Economy atau Ekonomi Biru. Ekonomi biru merupakan bentuk usaha dalam pembangunan daerah berbasis kelautan. Beberapa waktu yang lalu Indonesia menyampaikan usulan prinsip Ekonomi Biru dalam Forum Rio+20.Artinya, Pemerintah dan para pemangku kepentingan telah membangun kesadaran bersama untuk mengawali pembangunan daerah dengan mengutamakan potensi kelautan terutama bagi daerah berkarakter kepulauan dan wilayah pesisir. Bila hal ini dilakukan, secara sekuen akan terjadi pengaruh dan perubahan fundamental terhadap kesadaran global dalam pengelolaan laut dan sumber daya pesisir secara berkelanjutan selaras dengan harapan Forum Rio+20.

Menjadi lebih menarik ketika keikutsertaan publik yang diwujudnyatakan melalui partisipasi masyarakat turut mewarnai prosesi pembangunan dan pengelolaan potensi daerah kepulauan. Partisipasi masyarakat tersebut merupakan sumber daya yang besar dan dibutuhkan dalam pengelolaan dan pemanfaatan potensi kelautan yang dimiliki oleh setiap pemerintah daerah. Berdasarkan data yang diperoleh, potensi ekonomi di laut dan wilayah pesisir Indonesia mencapai US\$ 1,2 Trilyun pertahun, atau setara dengan 10 kali lipat anggaran pendapatan dan belanja negara (APBN) tahun 2012. Disinilah inovasi, kearifan lokal, dan partisipasi masyarakat menjadi strategis dan sangat dibutuhkan.

Dalam perspektif pembangunan daerah dan mencermati banyaknya daerah yang memiliki laut dan/atau berkarakter kepulauan, diperlukan metode khusus agar pemerintah, pemerintah daerah, dan masyarakat secara bersinergi dapatmenjaga, mengelola, mengembangkan, dan memanfaatkannya seoptimal mungkinsecara berkesinambungan tanpa meninggalkan permasalahan lingkungan. Dalam konteks ini, Pauli (2010) menawarkan konsep ekonomi biru yang menekankan pentingnya tata nilai baru, cara berpikir dan tindakan kolektif baru yang tidak menempatkan alam sebagai obyek. Selain itu, menekankan pentingnya memahami prinsip bagaimana alam bekerja, yang populer dengan istilah kembali ke alam (back to nature). Ekonomi biru lebih konstruktivistik dan nonlinier, sehingga kekhasan lokasi sangat diperhatikan (Satria, 2010).

Mengapa ekonomi biru? Berawal dari pertanyaan tersebut, timbul kuriositas untuk melakukan kajian potensi kewilayahan yang dimiliki kabupaten berciri kepulauan.Pilihan locusadalah Kabupaten Kepulauan Anambas yang terletak di kawasan Utara perbatasan antarnegaraIndonesia. Hal ini untuk menegaskan kembali bahwa keberadaan kabupaten/kota yang berwilayah laut dan/atau berciri kepulauanpatut mendapatkan perhatian Pemerintah secara khusus disertai komitmen/kesungguhan hati. Campur tangan ini menjadi penting, karena wilayah tersebut sesungguhnya menyimpan potensi besar yang luar biasa ketika dikelola secara professional dan benar untuk kesejahteraan masyarakat.

Kabupaten Kepulauan Anambas merupakan daerah otonom hasil pemekaran (DOHP) yang baru dibentuk berdasarkan Undang-Undang Nomor 33 Tahun 2008 tentang Pembentukan Kabupaten Kepulauan Anambas di Provinsi Kepulauan Riau. Secara geografis, Kabupaten Kep. Anambas terletak di perairan laut China Selatan, tepatnya pada posisi $2^{0} 10^{\prime} 0^{\prime \prime}-3^{0} 40^{\prime} 0{ }^{\prime} \mathrm{LU}$ s/d $105^{\circ} 15^{\prime} 0^{\prime \prime}-106^{\circ} 45^{\prime} 0^{\prime \prime}$ BT. Luas wilayah Kabupaten Kep. Anambas mencapai $46.664,14 \mathrm{Km}^{2}$ yang terdiri atas luas lautan mencapai $46.029,77 \mathrm{Km}^{2}$ atau $98,65 \%$ dan luas daratan yang hanya $634,37 \mathrm{Km}^{2}$ atau sekitar $1,35 \%$ dari total luas wilayah.

Keunikan karakter wilayah ini semakin nyata ketika mengamati batas-batas wilayah administrasi pemerintahannya. Sebelah Utara berbatasan dengan Laut Cina Selatan, sebelah Selatan dengan Kepulauan Tambelan, sebelah Barat dengan Laut Cina Selatan, dan sebelah Timur dengan Laut Natuna. Artinya, Kabupaten Kep. Anambas hanya bertetanggadengan wilayah laut. Menjadi semakin menantang bila ditinjau dari orbitasi wilayah yangmembuktikan bahwa letak Kabupaten Kep. Anambas berada pada wilayah terdepan Negara Kesatuan Republik Indonesia (NKRI), yakni perbatasan antarnegara. Dari ibukota kabupaten Tarempa ke ibukota Provinsi Kepulauan Riau membutuhkan waktu 16 jam perjalanan yang ditempuh melalui laut dan 1 jam melalui udara. Bila masyarakat ingin menuju ibukota Negara - Jakarta melalui jalur laut diperlukan waktu tempuh mencapai 70 jam atau 2,5 jam melalui udara. Hal ini sangat kontradiktif ketika masyarakat ingin bepergian ke Malaysia dan Singapura yang membutuhkan waktu tempuh tidak lebih dari 16 jam melalui jalur laut dan 45 menit melalui udara.Dalam perspektif demografis, jumlah penduduk Kabupaten Kep. Anambas sampai dengan tahun 2010 adalah 41.576 jiwa.Penduduk 


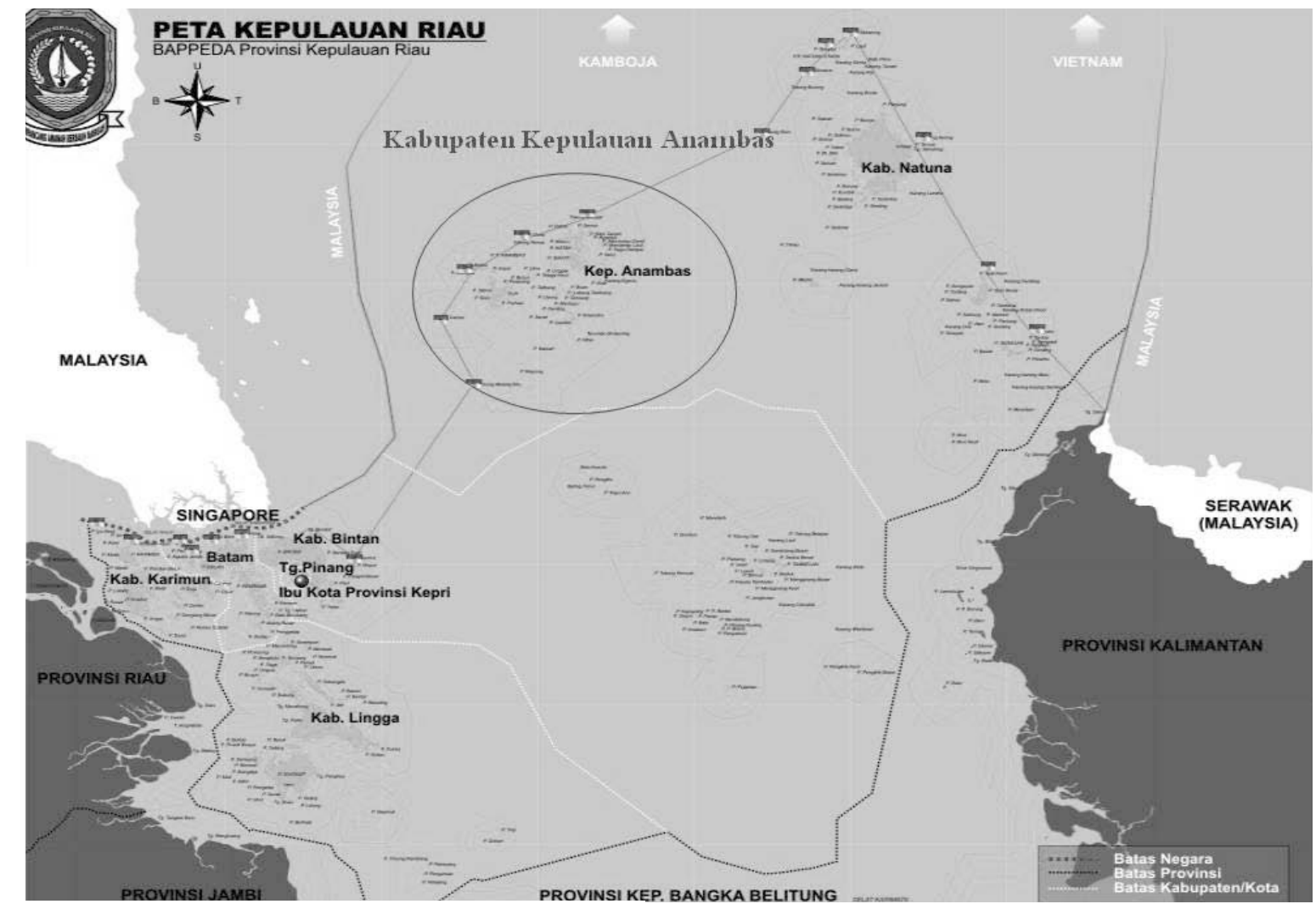

Sumber: Bappeda Kabupaten Kep. Anambas. 2012.

\section{Gambar 1. Peta Kabupaten Kepulauan Anambas - Provinsi Kepulauan Riau.}

laki-laki berjumlah 21.744 jiwa, sedangkan penduduk perempuan 19.832 jiwa. Angkatan kerja didominasi oleh profesi nelayan dan petani yang mencapai lebih dari $55 \%$ (Bappeda Kab. Kep. Anambas, 2012).

Ditinjau dari keberadaan Kabupaten Kep. Anambas nampak bahwa dalam konteks pembangunan daerah diperlukan metode (treatment) khusus yang terukur demi kemajuan sosial penduduk Kabupaten berciri kepulauan.Merujuk pada berbagai referensi, sampai saat ini belum terdapat definisi yang sama dan tetap untuk penyebutan daerah berciri kepulauan, khususnya di Indonesia. Kajian ini menggunakan definisi operasional untuk daerah berciri kepulauan adalah daerah otonom yang secara geografis berciri kepulauan, dimana komposisi wilayah laut lebih luas daripada wilayah daratan, terpisah dan tidak menjadi bagian wilayah daratan utama (mainland), dan terdiri atas pulau-pulau yang membentuk suatu gugusan pulau dengan fungsifungsinya sebagai satu kesatuan wilayah administratif penyelenggaraan pemerintahan daerah. Secara spesifik, pekerjaan penduduknya lebih didominasi oleh profesi yang bergerak untuk memanfaatkan berbagai potensi kelautannya.

Berdasarkan referensi dan dokumentasi serta hasil wawancara mendalamterhadap beberapa informan, berhasil diidentifikasi dan diinventarisasi permasalahan yang pada umumnya terjadi di wilayah kepulauan. Memerhatikan arah perkembangan (trend) jumlah penduduk Indonesia, penyelenggaraan pemerintahan daerah di wilayah kepulauan, dan mencermati kendala yang seringkali terjadi - bahkan menjadi persoalan utama di seluruh wilayah kepulauan di nusantara, diperlukan penanganan melalui strategi ekonomi biru.Dengan berbagai keterbatasannya, studi ini mencoba mengenalkan konsep ekonomi biru sebagai solusi pembangunan bagi wilayah kepulauan.

\section{Pembangunan Wilayah Kepulauan Berbasis Ekonomi Biru}

Mengacu pada prinsip-prinsip ekonomi biru, pembangunan wilayah kepulauan harus berorientasi pada tumbuhnya inovasi, penguatan partisipasi masyarakat, optimalisasi sumberdaya yang ada di sekitarnya, dan penggunaan teknologi yang berbasisbudaya dan kearifan lokal. Teknologi yang memanfaatkan potensi alam (cahaya matahari, angin, arus laut/sungai, dan gelombang laut) dan bahkan sampah atau limbah dikembangkan dengan sentuhan inovasi agar tidak merusak lingkungan melainkan memicu semangat dan kreativitas yang bernilai ekonomi dan bermanfaat untuk memenuhi kebutuhan masyarakat setempat.

Studi di Kabupaten Kep. Anambas berhasil mengidentifikasi beberapa permasalahan utama. Selain itu, Elfindri, dkk. (2009: 33-58) 
Matriks 1.

Dinamika Permasalahan di Daerah Kepulauan

(Studi Kasus: Kabupaten Kepulauan Anambas dan Daerah Kepulauan di Provinsi Kepulauan Riau)

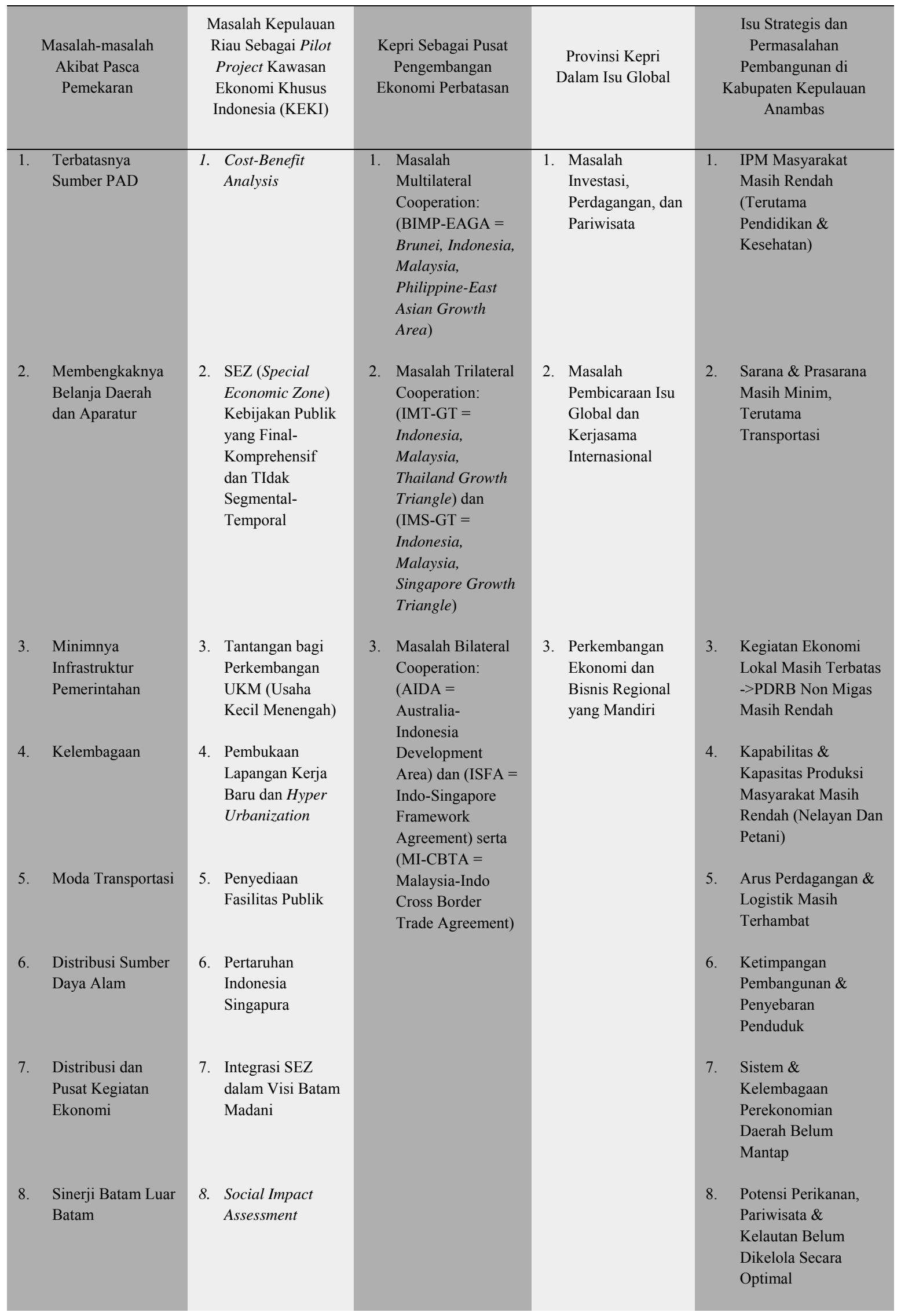




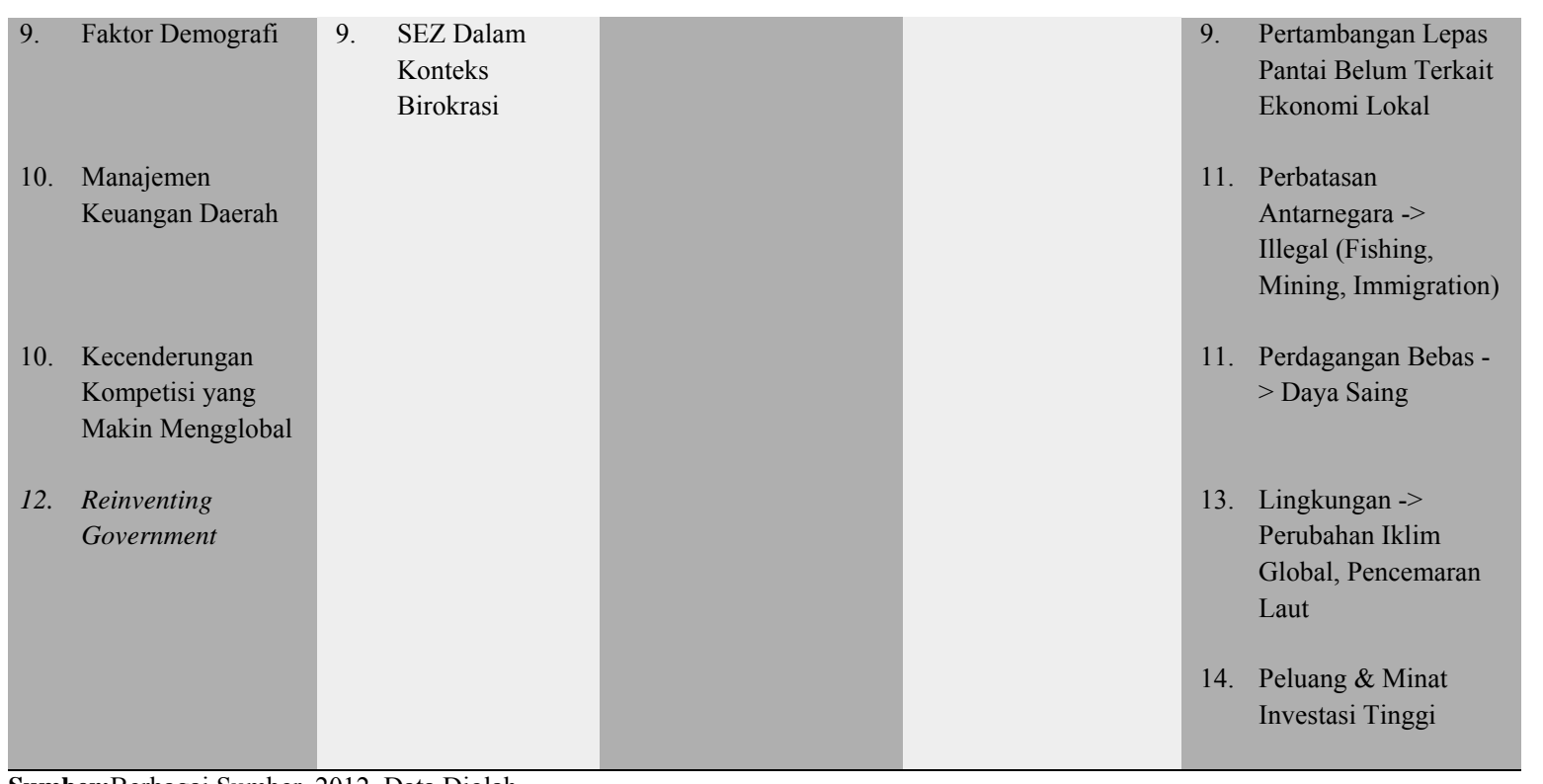

Sumber:Berbagai Sumber. 2012. Data Diolah.

berciri kepulauan pasca pemekaran. Secara ringkas, paduandinamika permasalahan tersebut diilustrasikan dalam Lampiran Matriks 1.

Pauli (2010) menyatakan bahwa ekonomi biru merupakan cara pengelolaan sumberdaya lokal dengan mengutamakan kepedulian sosial (social inclusiveness), memiliki prinsip efisiensi dan efektivitas, dilakukan secara kreatif-inovatif, dan dalam pemanfaatan materialnya tanpa menyisakan limbah. Sesungguhnya yang ingin dicapai adalah menjaga keseimbangan dalam pembangunan berkelanjutan (sustainable growth equity) terutama pada daerah berciri kepulauan. Sebab, keberadaan daerah kepulauan dengan fenomena alamnya memiliki kendala dan kesulitan tersendiri pada musim-musim tertentu.

Memadukan referensi berbagai literatur, ekonomi biru sangat bermanfaat untuk:

1. Optimalisasi potensi sebagai akibat dari kondisi geografis Indonesia - Negara Kepulauan (archipelagic state);

2. Mempertahankan kondisi laut, potensi sumber daya pesisir, dan penciptaan energi terbarukan;

3. Keberimbangan aspek ekonomi, sosial, budaya, dan lingkungan laut dalam menjaga kelestarian ekosistem laut;

4. Memperbanyak sumber pangan yang dapat diandalkan dan memastikan keberlangsungan ketahanan pangan masyarakat (terutama yang berasal dari laut untuk mereka yang bermukim di pesisir);

5. Menjamin perlindungan lingkungan dan kelestarian sumber daya alam, khususnya sektor kelautan dan perikanan;

6. Mempercepat pencapaian pertumbuhan yang berkelanjutan dan berkeadilan;

7. Penciptaan lapangan kerja baru dengan andalan mengoptimalisasikan jasa lingkungan dan nilai ekonomi (khususnya lautan) yang dapatmeningkatkan pendapatan;

8. Penguatan manajemen sumber daya laut lepas olahan melalui pendekatan ekosistem pengelolaan perikanan laut;

9. Pembinaan, pengawasan, pengendalian, supervisi, dan advokasi kelestarian lingkungan laut;

10. Perlindungan terhadap spesies langka;

11. Meningkatkan kesigapan, kesiapan, dan daya tahan masyarakat pesisir terhadap perubahan iklim dan bencana alam;

12. Mereduksi dampak pemanasan global, perubahan iklim, dan kenaikan permukaan laut, sehingga mampu menghasilkan oksigen $\left(\mathrm{O}_{2}\right)$ sebagai kebutuhan utama manusia; dan

13. Memicu inovasi dan kehadiran teknologi yang tepat agar diperoleh sumber "energialternatif".

Dalam perspektif pertumbuhan ekonomi, wilayah kepulauan memiliki potensi wisata yang lebih variatif. Memadukan potensi alam wilayah kepulauan seperti matahari, pasir putih, dan laut (sun, white sand, and sea) akan menumbuhkan industri pariwisata dan industri kreatif di daerah. Sekalipun harus diakui, faktor aksesibilitas dan konektivitas (keterhubungan) menjadi kendala utama. Penyiapan infrastruktur menjadi prioritas utama, sehingga daya jangkau dan waktu tempuh dalam konteks penyelenggaraan pemerintahan, pengusahaan (business), dan pelayanan publik dapat tersedia dengan baik dan terpenuhi secara tepat waktu. Penekanannya pada sinergisitas pembangunan berbasis potensi masyarakat yang disinergikan dengan pembangunan berbasis potensi alam.

Secara sederhana, aktualisasi ekonomi biru dapat diwujudkan melalui penyediaan infrastruktur yang dapat meningkatkan aksesibilitas dan konektivitas, inovasi yang diimbangi dengan terjaganya kearifan 
lokal, pendayagunaan potensi masyarakat disertaipartisipasi dan perubahan budaya menuju masyarakat yang lebih berdaya.Inilah kondisi yang harus diaktualisasikan bagi penyelenggaraan pemerintahan di daerah terpencil, tertinggal, terbelakang, terisolir, dan/atau berciri kepulauan. Partisipasi masyarakatnya dapat dilakukan dengan cara memberikan ruang dan waktu untuk mengekspresikan pengetahuan, aspirasi, dan pendapatnya secara individual maupun kelompok terhadap "proses-implementasi-evaluasi" regulasi dan/atau kebijakan publik, sehingga tercipta tanggung jawab dan tumbuhnya rasa memiliki (sense of belonging) atas penyelenggaraan pemerintahan daerah.

\section{METODE PENELITIAN}

Studi ini merupakan bagian dari aktivitas kelitbangan, yakni pengkajian.Tujuanyang hendak dicapai adalah menemukan solusi untuk pembangunan daerah berciri kepulauan. Studi dilakukan di Kabupaten Kep. Anambas Provinsi Kepulauan Riau (Kepri) dengan pendekatan kualitatif. Pengkajian menggunakan metode deskriptif berbasis analisis eksploratif.

\section{HASIL DAN PEMBAHASAN}

Indonesia sebagai Negara kepulauan memiliki sumberdaya alam laut yang potensial. Menjadi suatu keharusan bagi Pemerintah untuk merubah haluan pembangunannya dengan memanfaatkan potensi kelautan sebagai penggerak utama (prime mover) pertumbuhan ekonomi dalam negeri. Namun, Pemerintah belum fokus dalam menata, membenahi, dan memfasilitasi masyarakat maupun dunia usaha yang ingin mengimplementasikan konsepsi pembangunan kelautan berbasis ekonomi biru.Paradigma pembangunan yang berorientasi kelautan menuntut komitmen yang tinggi. Para pemangku kepentingan harus merumuskan regulasi yang komprehensif termasuk insentif yang diperlukan, mendidik sumberdaya manusia (SDM) pengelola yang akan terus berkreasi secara inovatif, dan berupaya mencari investor yang mau menanamkan modalnya pada pembangunan infrastruktur kelautan dan perikanan.

Solusi konvergensi harus mampu memadukan sejumlah ide yang mencakup inovasi dunia usaha, kreativitas masyarakat, dan regulasi Pemerintah dalam skala nasional dan pemerintahan daerah dalam skala lokal. Pemerintah sudah selayaknya segera merumuskan skema bisnis dan manajemen yang terintegrasi dengan sumberdaya lokal dan karakteristik kewilayahan sebagai kerangka pengembangan kawasan laut dan perairan daerah. Skema ini harus memertimbangkan 5E, yakni: 1) ekologi; 2) energi; 3) efisiensi; 3) efektivitas; 4) energi; dan 5) ekonomis.Artinya, skema bisnis dan manajemen pengembangan wilayah harus mudah dipahami dan dilakukan oleh para pengguna (user friendly). Bahkan, skema tersebut idealnya telah mengadopsi aspirasi yang berkembang di masyarakat. Pada bagian akhir, sosialisasi melalui media massa cetak maupun elektronik menjadi bagian penting untuk merubah cara berpikir dan bertindak menuju paradigma pembangunan daerah berciri kepulauan.

Berbekal jumlah pulau dan luasnya wilayah laut pada 317 pemerintah daerah kabupaten/kota, maka sudah selayaknya bila Pemerintah segera mengawali agenda membumikan ekonomi biru di Indonesia. Pemerintah punharus berani melakukan transformasi cara pandang, cara berpikir, dan cara bertindak, sehingga terjadi perubahan konsep pembangunan di daerah menuju ke arah pembangunan berbasis ekonomi biru.Hal ini sejalan dengan pernyataan Satria (2012) bahwa dalam ekonomi, dituntut inovasi dan kreativitas tinggi untuk bisa menemukan siklus alam yang lalu menjadi inspirasi bagi sebuah aktivitas ekonomi lokal yang bersih. Inovasi dan kreativitas yang tercipta akan berimplikasi pada kemandirian lokal.

Dalam konteks ini, ekonomi biru wajib dimanfaatkan sebagai basis manajemen dan bisnis, sehingga mampu mengakselerasi pembangunan daerah kepulauan agar lebih produktif dan memeroleh hasil yanglebih berkualitas dan optimal. Implikasinya, melalui pelibatan masyarakat dalam setiap proses produksi, maka tercipta lapangan kerja dan terjadi peningkatan pendapatan perkapita secara lebih merata. Akhirnya, ekonomi biru dapat menjadi groundbreaking sekaligus referensi perumusan model pembangunan komprehensif dan sistemik di daerah berciri kepulauan.

Dalam mengimplementasikan "ekonomi biru", tentunya Pemerintahan Daerah wajib menyusun roadmap pembangunan daerah kepulauan dan mengintegrasikannya ke dalam Dokumen Perencanaan Pembangunan Daerah. Intinya, pengelolaan dilakukan secara tepat, sedangkan pemanfaatan SDAdilakukan secara optimal melalui inovasi dan kreatifitas serta budi daya yang menjunjung harkat dan martabat bangsa.

Faktor terpenting adalah komitmen Pemerintah dan Pemerintahan Daerah untuk berkolaborasi dengan dunia usaha (swasta) melalui pengintegrasian kekuatan dunia kelitbangan (research and development) dengan dunia pendidikan yang dinamis.

Sebagaimana diisyaratkan oleh Pauli (2012) terdapat 5 (lima) poin penting di dalam pengembangan ekonomi biru (Blue Economy) di Indonesia, yakni:

1. Pemerintah agar mengindentifikasi peluangpeluang investasi di sektor kelautan dan perikanan yang dapat dikembangkan berbasis Blue Economy. 
2. Mengembangkan usaha dan investasi berbasis model blue economy, yang dimulai dari beberapa kegiatan utama seperti budidaya rumput laut, artemia, garam, pakan ikan, perikanan tangkap, dan pengelolaan pulau-pulau kecil berkelanjutan yang mengantisipasi isu ketahanan energi, pangan, dan air bersih.

3. Pengembangan sumber daya manusia (SDM) di bidang kelautan dan perikanan melalui pelatihan pemuda dan calon pengusaha-pengusaha muda.

4. Pengembangan dokumentasi dan materi Blue Economy untuk publik.

5. Upaya untuk mempromosikan penyelenggaraan dan partisipasi bersama dalam pertemuan internasional.

Maknanya, melalui ekonomi biru diharapkan tercipta kreativitas dan inovasi dalam rangka efisiensi, efektivitas, keekonomian, dan produktivitas ketika masyarakat memanfaatkan potensi sumberdaya lokal. Kreativitas dan inovasi dalam ekonomi biru harus mampu menjamin keberlangsungan produk turunan yang berkualitas tanpa meninggalkan limbah, sehingga memiliki harga yang kompetitif sekaligus menjaga kelestarian lingkungan. Dengan kata lain, melalui penerapan ekonomi biru dalam konteks pembangunan daerah, maka masyarakat di wilayah kepulauan akan memiliki memperoleh keuntungan dan meningkatkan pendapatan. Masyarakat di wilayah kepulauan pun tidak harus meninggalkan kampung halamannya karena terbuka kesempatan kerja yang menyerap tenaga kerja melalui peningkatan nilai tambah ekonomi.

Dalam perspektif penyelenggaraan pemerintahan daerah, terdapat 2 (dua) hal yang harus dilakukan, yakni pertama, Pemerintah maupun pemerintah daerah bersama-sama membangun komitmen untuk mengintegrasikan konsep pembangunan di wilayah daratan sebagai langkah penguatan konsep pembangunan berbasis laut (ekonomi biru). Artinya, memerhatikan dominasi jumlah kabupaten/kota yang memiliki wilayah laut dan berciri kepulauan, maka sudah saatnya dilakukan penyatuan konsep pembangunan dengan merubah orientasi pembangunan berbasis laut. Kedua, mengalokasikan anggaran secara proporsional agar bermanfaat bagi setiap pemerintah daerah untuk mengelola wilayah lautnya, sehingga menghasilkan produk khas yang kompetitif dan bernilai tambah. Dengan kata lain, diperlukan keberanian, ketegasan, dan keberpihakanPemerintah maupun pemerintah daerah dalam pengalokasian anggaran melalui APBN dan APBD sebagaiwujud dukungan terhadap pembangunan kelautan yang berdaya saing. Sebab, melalui ekonomi biru dapat disinergikan berbagai kepentingan masyarakat, bisnis, dan birokrasi yang bergerak di sektor transportasi darat-laut-darat, industri maritim, kepariwisataan, energi dan sumberdaya mineral, serta kelautan dan perikanan. Hal ini demi terwujudnya sinkronisasi, harmonisasi, keterpaduan,dan kesinambungan program/kegiatan per sektor, sehingga memacu kegiatan ekonomi berkelanjutan di wilayah kepulauan.

Melalui ekonomi biru, pembangunan daerah harus terfokus kepada perencanaan, pengorganisasian, pelaksanaan, pengendalian, dan pengawasan pembangunan yang berorientasi pada upaya:

1. penataan ruang laut, perairan, dan kawasan pesisir;

2. pengembangan kapasitas masyarakat terutama nelayan;

3. pemanfaatan sumberdaya kelautan dan perairan secara efektif dan produktif;

4. penjagaanterhadap keseimbangan dan keberlanjutan ekosistem;

5. penjaminan stok sumberdaya ikan;

6. peningkatan daya dukung lingkungan;

7. penguatan inovasi teknologi kelautan dan perikanan;

8. pembangunan industri perikanan tangkap yang ramah lingkungan;

9. penyadaran terhadap pentingnya pantai dan lautan serta perairan; dan

10. pelestarian keanekaragaman hayati laut.

Ekonomi biru mengandalkan manajemen pembangunan yang bersifat inklusif, sehingga masyarakat dapat mengoptimalkan potensi kelautan untuk dikelola dalam upaya mencapai kesejahteraan. Dalam perspektif sosio-ekonomi, terdapat beberapa potensi kelautan yang layak dikelola melalui pola budidaya, diantaranya adalah: 1) rumput laut; 2) udang; 3) ikan tongkol; dan 4) ikan tuna dan cakalang.

Kunci keberhasilan penyelenggaraan ekonomi biru sebagai solusi pembangunan daerah berciri kepulauan adalah terselenggaranya koordinasi kebijakan baik dalam skala nasional, regional, maupun internasional. Argumentasinya sederhana, karena laut merupakan common property, yakni: sebagai sumber pangan, oksigen, air, dan kehidupan habitat yang tanpa batas.

Pemerintah patut pula memertimbangkan luasan wilayah laut yang mendominasi luas wilayah NKRI sebagai dasar penetapan anggaran pembangunan Pusat maupun daerah. Sebab, besaran alokasi anggaran ini mengindikasikan semangat perubahan yang disertai komitmen dan keberpihakan sekaligus membuktikan konsistensi Pemerintah terhadap orientasi pembangunan daerah yang berciri kepulauan. Hanya melalui kebijakan anggaran inilah dapat disusun perencanaan yang matang agar mampu mereduksi rumah tangga miskin, hampir miskin, dan sangat miskin di kelompok keluarga nelayan. Dengan kata lain, memerhatikan luas laut dan perairan di Indonesia seharusnya memberikan kontribusi yang lebih tinggi terhadap penerimaan negara, sehingga dapat memakmurkan masyarakat terutama mereka yang hidup di kawasan pesisir dan/atau memiliki mata pencaharian bergantung pada laut/perairan. 
Tabel 3. Komposisi Luas Wilayah Laut Administrasi Pemerintahan Daerah MenurutKabupaten/Kota - Tahun 2011

\begin{tabular}{|c|c|c|c|c|c|c|c|c|}
\hline \multirow{3}{*}{ No. } & \multirow{3}{*}{ Provinsi } & \multicolumn{7}{|c|}{ Wilayah Laut Administrasi Pemerintahan Daerah } \\
\hline & & \multicolumn{2}{|c|}{ Luas Wilayah Provinsi } & \multicolumn{2}{|c|}{$\begin{array}{c}\text { Kabupaten } \\
\text { Berwilayah Laut }\end{array}$} & \multicolumn{2}{|c|}{$\begin{array}{c}\text { Kota Berwilayah } \\
\text { Laut }\end{array}$} & Jumlah \\
\hline & & Darat $\left(\mathrm{Km}^{2}\right)$ & Laut $\left(\mathrm{Km}^{2}\right)$ & $\Sigma_{1}$ & $\begin{array}{l}\text { Luas Wil. } \\
\text { Laut }\left(\mathrm{Km}^{2}\right)\end{array}$ & $\Sigma_{2}$ & $\begin{array}{l}\text { Luas Wil. } \\
\text { Laut }\left(\mathrm{Km}^{2}\right)\end{array}$ & $\left(\Sigma_{1}+\Sigma_{2}\right)$ \\
\hline 1. & Aceh & $57.956,00$ & $42.665,67$ & 14 & $13.748,35$ & 4 & 958,40 & 18 \\
\hline 2. & Sumatera Utara & $72.981,23$ & $39.934,79$ & 13 & $13.842,84$ & 3 & 351,04 & 16 \\
\hline 3. & Sumatera Barat & $42.012,89$ & $32.700,70$ & 5 & $11.399,25$ & 2 & 704,86 & 7 \\
\hline 4. & Riau & $87.023,66$ & $16.736,13$ & 6 & $7.127,89$ & 1 & 569,28 & 7 \\
\hline 5. & Kepulauan Riau & $8.201,72$ & $79.689,41$ & 5 & $28.185,32$ & 2 & $2.307,53$ & 7 \\
\hline 6. & Jambi & $50.058,16$ & $4.671,98$ & 2 & $1.613,95$ & 0 & 0 & 2 \\
\hline 7. & Sumatera Selatan & $91.592,43$ & $7.541,08$ & 3 & $3.040,41$ & 0 & 0 & 3 \\
\hline 8. & Kep. Bangka Belitung & $16.424,06$ & $37.348,53$ & 6 & $13.211,05$ & 1 & 58,25 & 7 \\
\hline 9. & Bengkulu & $19.919,33$ & $14.929,54$ & 6 & $4.034,32$ & 1 & 395,33 & 7 \\
\hline \multirow[t]{2}{*}{10.} & Lampung & $34.623,80$ & $17.757,63$ & 6 & $7.508,99$ & 1 & 74,40 & 7 \\
\hline & SUMATERA & $480.793,28$ & $293.975,46$ & 66 & $103.712,37$ & 15 & $5.419,09$ & 81 \\
\hline 11. & DKI Jakarta & 664,01 & $5.674,35$ & 1 & & 1 & & 2 \\
\hline 12. & Jawa Barat & $35.377,76$ & $15.634,40$ & 10 & $5.170,48$ & 1 & 37,33 & 11 \\
\hline 13. & Banten & $9.662,92$ & $10.952,54$ & 4 & $4.301,58$ & 2 & 381,48 & 6 \\
\hline 14. & Jawa Tengah & $32.800,69$ & $16.892,28$ & 14 & $5.530,38$ & 3 & 177,69 & 17 \\
\hline 15. & DI Yogyakarta & $3.133,15$ & $2.277,31$ & 3 & 758,85 & 0 & 0 & 3 \\
\hline \multirow{2}{*}{16.} & Jawa Timur & $47.799,75$ & $53.799,75$ & 19 & $18.562,98$ & 3 & 231,51 & 22 \\
\hline & JAWA & $129.438,28$ & $105.230,63$ & 51 & $34.324,27$ & 10 & 828,01 & 61 \\
\hline 17. & Bali & $5.780,06$ & $9.211,76$ & 7 & $3.218,14$ & 1 & 108,66 & 8 \\
\hline 18. & Nusa Tenggara Barat & $18.572,32$ & $27.676,76$ & 8 & $12.628,42$ & 2 & 77,75 & 10 \\
\hline \multirow[t]{2}{*}{19.} & Nusa Tenggara Timur & $48.718,10$ & $80.134,69$ & 20 & $29.963,47$ & 1 & 52,20 & 21 \\
\hline & BALI - NUSTRA & $73.070,48$ & $117.023,21$ & 35 & $45.810,03$ & 4 & 238,61 & 39 \\
\hline 20. & Kalimantan Barat & $147.307,00$ & $34.169,95$ & 6 & $13.240,58$ & 1 & 136,87 & 7 \\
\hline 21. & Kalimantan Tengah & $153.564,50$ & $12.273,06$ & 7 & $4.499,80$ & 0 & 0 & 7 \\
\hline 22. & Kalimantan Selatan & $38.744,23$ & $20.317,22$ & 5 & $7.071,51$ & 0 & 0 & 5 \\
\hline \multirow[t]{2}{*}{23.} & Kalimantan Timur & $204.534,34$ & $33.094,59$ & 8 & $12.881,38$ & 3 & $1.075,42$ & 11 \\
\hline & KALIMANTAN & $544.150,07$ & $99.854,82$ & 26 & $37.693,27$ & 4 & $1.212,29$ & 30 \\
\hline 24. & Sulawesi Utara & $13.851,64$ & $44.647,54$ & 11 & $13.522,43$ & 2 & 580,91 & 13 \\
\hline 25. & Gorontalo & $11.257,07$ & $9.241,57$ & 5 & $3.753,65$ & 1 & 60,72 & 6 \\
\hline 26. & Sulawesi Tengah & $61.841,29$ & $67.057,16$ & 9 & $28.833,75$ & 1 & 94,94 & 10 \\
\hline 27. & Sulawesi Selatan & $46.717,48$ & $78.710,59$ & 15 & $29.004,23$ & 3 & 538,79 & 18 \\
\hline 28. & Sulawesi Barat & $16.787,18$ & $20.342,41$ & 4 & $5.953,86$ & 0 & 0 & 4 \\
\hline \multirow[t]{2}{*}{29.} & Sulawesi Tenggara & $38.067,70$ & $47.781,32$ & 10 & $18.642,05$ & 2 & 312,47 & 12 \\
\hline & SULAWESI & $188.522,36$ & $267.780,59$ & 54 & $99.709,97$ & 9 & $1.587,83$ & 63 \\
\hline 30. & Maluku & $46.914,03$ & $146.945,10$ & 9 & $49.115,77$ & 2 & $3.023,36$ & 11 \\
\hline \multirow[t]{2}{*}{31.} & Maluku Utara & $31.982,50$ & $88.304,40$ & 7 & $34.240,77$ & 2 & $1.846,76$ & 9 \\
\hline & MALUKU & $78.896,53$ & $235.249,50$ & 16 & $83.356,54$ & 4 & $4.870,12$ & 20 \\
\hline 32. & Papua & $319.036,05$ & $86.830,52$ & 12 & $34.556,38$ & 1 & 421,20 & 13 \\
\hline \multirow[t]{3}{*}{33.} & Papua Barat & $97.024,27$ & $103.393,26$ & 9 & $43.210,01$ & 1 & 438,41 & 10 \\
\hline & PAPUA & $416.060,32$ & $190.223,78$ & 21 & $77.766,39$ & 2 & 859,61 & 23 \\
\hline & INDONESIA & $1.910 .931,32$ & $1.309 .337,99$ & 269 & $482.372,84$ & 48 & $15.015,56$ & 317 \\
\hline
\end{tabular}

Sumber: Ditjen PUM Kemendagri dan Badan Informasi Geospasial (BIG). Data Diolah. 2012.

Menjadi menarik bila kita mampu mengelola pembangunan daerah berbasis ekonomi biru sebagaimana yang diterapkan oleh China, yakni fokus pada aspek ekonomi kelautan, tanggung jawab sosial perusahaan, kesadaran manajemen pengetahuan, status kesehatan laut (pencemaran), dan manajemen kelautan. Secara spesifik, melalui ekonomi biru dapat dikelola ketahanan pangan, energi terbarukan, komunikasi, transportasi, dan konektivitas, kesehatan lingkungan, dan mitigasi bencana disertai persiapan tanggap darurat.

\section{SIMPULAN}

\section{A. Simpulan}

Ekonomi biru Indonesia merupakan solusi terhadap tuntutan dinamika pelayanan, meningkatnya kebutuhan hidup masyarakat di kepulauan, dan keterbatasan yang dimiliki dan mampu disediakan 
oleh Pemerintah maupun pemerintah daerah dalam pengelolaan pembangunan daerah berciri kepulauan. Pemerintah daerah yang memiliki wilayah laut dan perairan yang luas menuntut mekanisme pengelolaan dan manajemen profesional agar dapat memberikan lapangan kerja baru, meningkatkan pendapatan masyarakat, mendorong ketahanan pangan, menjaga kualitas kelautan, dan menjamin lestarinya lingkungan. Selain itu, pembangunan daerah kepulauanberbasis ekonomi biru menstimulasi pertumbuhan sumber-sumber perekonomian baru yang lebih kompetitif. Melalui ekonomi biru, masyarakat dan para pemangku kepentingan diajak meningkatkan pertumbuhan ekonomi, mendorong kemajuan social,dan mewujudkan lingkungan yang sehat melalui pengelolaan sumberdaya lokal secara ekologis sebagai potensi wilayah kepulauan demi meraih keuntungan.

\section{B. Rekomendasi}

Pembangunan daerah berciri kepulauan berbasis ekonomi biru akan berhasil bila Pemerintah maupun pemerintah daerah berkomitmen, berpihak, dan berani serta tegas dalam mengintegrasikan program/kegiatan pembangunan berbasis darat sebagai wujud dukungan percepatan pembangunan kelautan secara komprehensif.

Perubahan orientasi pembangunan ini pun harus didukung dengan komitmen dan keberpihakan dalam pengalokasian anggaran pembangunan (APBN dan APBD) secara proporsional di setiap daerah berciri kepulauan.

Dalam upaya membumikan ekonomi biru, arah kebijakan program/kegiatan di setiap kementerian/lembaga agar saling melebur secara koordinatif-teknis. Kondisi ini dimaksudkan agar dapat dirumuskan regulasi/kebijakan pembangunan berbasis ekonomi yang inovatif dan khas keindonesiaan, tanpa harus meninggalkan kearifan dan budaya lokal.Keterlibatan dan partisipasi aktif setiap elemen masyarakat menjadi penting demi optimalisasi pemanfaatan bahan baku yang sudah tersedia di daerah agar terjadi percepatan pengembangan perekonomian di wilayah kepulauan.

Selain itu, diperlukan kebersamaan diantara para pemangku kepentingan dalam perumusan kebijakan yang lebih komprehensif-sinergis untuk penanganan berbagai persoalan pembangunan di daerah yang berciri kepulauan, terutamakepulauan yangberada di kawasan perbatasan antarnegara.

\section{DAFTAR PUSTAKA}

Adisasmita, Rahardjo. 2010. Pembangunan Kawasan dan Tata Ruang. Cetakan Pertama. Yogyakarta: Graha Ilmu.

Briones, Roehlano M., and Arnulfo G. Garcia. 2008. Poverty Reduction Through Sustainable Fisheries: Emerging Policy and Governance Issuess in Southeast Asia. First Published in Singapore by Institute of Southeast Asian Studies (ISEAS) and
Southeast Asian Regional Center for Graduate Study and Research in Agriculture (SEARCA) College, Los Banos, Laguna, Philippines. Printed in Singapore by Markono Print Media Pte., Ltd.

Connors, Rogers and Tom Smith. 2011.Change the Culture, Change the Game: The Breakthrough Strategy for Energizing Your Organization and Creating Accountability for Results. First Published in the United States of America by Portfolio/Penguin, a member of Penguin Group, New York, USA.

Cribb, Robert and Michele Ford. 2009. Indonesia Beyond the Water's Edge: Managing an Archipelagic State. First Published in Singapore by Institute of Southeast Asian Studies (ISEAS). Printed in Singapore by Utopia Press Pte., Ltd.

Elfindri, Jemmy Rumengan, Syamsul Bahrum, Tengku Dahril, Rimilton Riduan, dan Zainal Abidin. 2009. Manajemen Pembangunan Kepulauan. Cetakan Pertama. Baduose Media.

Kementerian Dalam Negeri, Direktorat Jenderal Pemerintahan Umum (Ditjen PUM). 2011. Peraturan Menteri Dalam Negeri Nomor 66 Tahun 2011 Tentang Kode dan Data Wilayah Administrasi Pemerintahan dalam Buku Induk. Jakarta: Ditjen PUM.

Kusnanto, Hari. 2011. Adaptasi Terhadap Perubahan Iklim. Edisi Pertama, Cetakan Pertama. Yogyakarta: BPFE-Yogyakarta.

Nugroho, Hanan. 2012. Energi Dalam Perencanaan Pembangunan. Cetakan Pertama. Bogor: PT Penerbit IPB Press.

Orstrom, Moller, J. 2011. How Asia Can Shape The World: From The Era of Plenty to The Era of Scarcities. First Published in Singapore by Institute of Southeast Asian Studies (ISEAS). Printed in Singapore by Utopia Press Pte., Ltd.

Pauli, Gunter A. 2010. The Blue Economy: 10 Years, 100 Innovations, 100 Million Jobs. Report to the Club of Rome. Published by Paradigm Publications, Taos, New Mexico, USA.

Roumasset, James A., Kimberly M. Burnett, and Arsenio M. Balisacan. 2010. Sustainability Science for Watershed Landscapes. First Published in Singapore by Institute of Southeast Asian Studies (ISEAS) and Southeast Asian Regional Center for Graduate Study and Research in Agriculture (SEARCA) College, Los Banos, Laguna, Philippines. Printed in Singapore by Markono Print Media Pte., Ltd.

Rumelt, Richard P. 2012. Good Strategy Bad Strategy: The Difference and Why It Matters. First Published in Great Britain in 2011 by Profile Books Ltd. London. Printed and Bound in Great Britain by CPI Group (UK) Ltd. Croydon, CR0 4YY.

Satria, Arif. 2012. Ekonomi Biru. Harian Kompas, Terbitan 15 Desember 2012. Jakarta.

Sumodiningrat, Gunawan. 2009. Mewujudkan Kesejahteraan Bangsa: Menanggulangi Kemiskinan dengan Prinsip Pemberdayaan Masyarakat. Jakarta: Penerbit PT. Elex Media Komputindo. 
12 | Jurnal Bina Praja| Volume 5 Nomor 1 Edisi Maret 2013: 1 - 12 